\title{
PUDJANGGA BARU: ASPECTS OF INDONESIAN INTELLECTUAL LIFE IN THE $1930 \mathrm{~s}$
}

\author{
Heather Sutherland
}

Pudjangga Baru, the "New Writer," was a cultural periodical put out in the colonial capital of Batavia by a group of young Indonesian intellectuals from 1933 until the invasion of the Netherlands Indies by Japan in 1942.1 In Bahasa Indonesia, the term pudjangga means "literary man, man of letters; author, poet; linguist, philologist." 2 The choice of this term for the title of the monthly was no doubt also influenced by an awareness of its historical connotations, for the word can be traced back through such 0ld Javanese forms as bhujanga to an original Sanskrit root associated with sacred and priestly learning. It implied nobility and integrity as well as literary ability; and it is therefore no accident that the writings appearing in it claimed high idealism and a sense of mission.

The purpose proclaimed by Pudjangga Baru became more fervent as the years passed. In the beginning, it described itself simply as a literary, artistic, and cultural monthly. At the start of its third year it declared itself a "bearer of a new spirit in literature, art, culture, and general social affairs." 3 At the beginning of its fifth year it claimed to be the "leader of the new dynamic spirit to create a new culture, the culture of Indonesian unity." 4 In 1928, when the second All-Indonesia Youth Congress swore the famous oath to work for "one fatherland, one people, and one language" Pudjangga Baru pledged itself to work for the development of the national language and also to strive for a national culture, adding "one culture" to its

1. A post-independence series, which was published from 1948 to 1954 under the same title, is not considered in this discussion. Some ninety issues of the pre-war magazine appeared; it was officially a monthly, but many of its numbers were combined issues covering a period of two or three months.

2. S. Wojowasito and W. J. S. Poerwadarminta, Kamus Indonesia Inggeris (paperback), Djakarta, 1964, p. 178. For a discussion of the historical term, see J. M. van der Kroef, "The Javanese Term Boedjangga," Journal of the American Oriental Society (LXX), 1950, pp. 73-76; and F. D. K. Bosch: "Nogmaals Oud-Javaans Bhujanga," Bingkisan Budi (Leiden: Sijthoff, 1950), pp. 42-49.

3. Quoted in A. Teeuw, Pokok dan Tokoh dalam Kesusasteraan Indonesia (Djakarta: Pembangunan, 1955), I, p. 55.

4. Ibid. 
version of the Youth 0ath. These declarations of confident ambition seem to have been justified, for the journal was to give its name not only to a particular group of writers and critics but also to a certain cultural viewpoint, becoming in the end identified with the poetry and essays of pre-war Indonesian literature.

Pudjangga Baru was established by three young Sumatrans: Sutan Takdir Alisjahbana, Amir Hamzah, and Armijn Pané. A prospectus--probably written by Takdiris--was issued prior to its appearance, declaring that:

Until now there has been very little communication between poets and authors who become more numerous day by day. Each one works alone, paying no attention to the others, only making use of the opportunities other people grant him. . . ${ }^{6}$

The author described the opportunities permitted a writer and found them inadequate, consisting as they did--outside the government-controlled publishing house Balai Pustaka--of newspapers and periodicals which published poetry and short stories as a sideline or as fillers, but which were not primarily interested in cultural affairs. He asserted that there was an increasing demand for a periodical which would put literature first, would unite and give leadership to the scattered Indonesian writers, and would work on the clarification and development of Bahasa Indonesia.

An awareness of the need for a means of literary coordination and publicity had existed since the 1920s, when modern Indonesian writing had first appeared from the pens of Marah Rusli, Sanusi Pane, Muhammad Yamin, and Rustam Effendi, and several efforts to establish a regular publication had been made before success was finally achieved with the founding of Pudjangga Baru. ${ }^{7}$ The new journal had a very small circulation, its paid

5. H. B. Jassin, Pudjangga Baru: Prosa dan Puisi (Djakarta: Gunung Agung, 1963), P. 8 .

6. See Bakri Siregar, Sedjarah Sastra Indonesia Modern (Djakarta: Akademi Sastra dan Bahasa Multatuli, 1964), PP. 75-78, which quotes extensively from the prospectus.

7. The pioneering work of modern Indonesian literature was Marah Rusli's novel Sitti Nurbaja, issued in 1922 by Balai Pustaka. The verse of Muhammad Yamin, also new in form, was published by the magazine Jong Sumatra in 1921. The formation of a literary journal, Malaya, was advertised in 1921, and in the same year the Sumatran Youth Congress sponsored the publication of a collection of modern literature. In 1925 a group of intellectuals including Sanusi Pané, Rustam Effendi, and Muhammad Yamin tried to establish a literary magazine; but 
subscriptions never exceeding one hundred and fifty. ${ }^{8}$ It was not a commercial proposition, and, in fact, had to be subsidized by Armijn Pané and Takdir. But this small clientele does not give an accurate impression of Pudjangga Baru's influence. The public interested in reading an avante garde "little magazine" is small in any country, and it was naturally still smaller in colonial Indonesia, where Western education was available only to a minority and where the reading habit was not widely established.

Moreover, the Indonesian intellectuals of the time were accustomed to speaking a regional language in family conversation and Dutch in more formal discourse. The hold of. Dutch on the modern-educated elite was so strong that one scholar of the day declared the Indonesian intellectual, "as a result of his Western education, has practially forgotten his own language." 9 The fact that Pudjangga Baru published only in Bahasa Indonesia limited its appeal among those accustomed to thinking in Dutch or, say, Javanese, for they often were insufficiently fluent in Malay to be able to read the journal with enough ease to make its contents seem worthwhile. Pudjangga Baru was received with enthusiasm by small groups of young writers, poets, and teachers-particularly the teachers of the independent "wild schools"-but many of the established literati and teachers of Malay regarded it with disapproval, for they saw it as corrupting still adequate traditional forms by its modern experimentation.10

Throughout Pudjangga Baru's lifetime, its main emphasis was on poetry and critical essays. It published over three hundred individual poems as well as several collections of verse; ${ }^{11}$

their effort failed, as did an attempt made four years later by Armijn Pané. See Jassin, Pudjangga Baru, PP. 7-8, note 2 .

8. Teeuw, Pokok dan Tokoh, I, P. 56. The actual number who read the magazine was actually considerably larger; for subscribers circulated their copies among friends and interested acquaintances.

9. G. W. Drewes, "The Influence of Western Civilization on the Languages of the East Indian Archipelago," in B. J. 0 . Schrieke (ed.), The Effect of Western Influence on Native Civilisations in the Malay Archipelago (Batavia: Kolff, 1929), P. 155 .

10. Jassin, Pudjangga Baru, p. 12 .

11. Special issues of Pudjangga Baru were devoted to Takdir Alisjahbana's collection "Tebaran Mega" and to two volumes of Amir Hamzah's poems, "Njanji Sunji" and "Buah Rindu." See Pudjangga Baru (hereafter cited as P.B.) (III, 11), May 1936, PP. 288-310; P.B. (IV, 4), October 1937, PP. 107-124; P.B. (VIII, 12), June 1941, Pp. 319-346. A volume of verse 
in addition to numerous individual articles, it issued a commemorative volume of essays on Raden Adjeng Kartini and another on Rabindranath Tagore. 12 The journal published four complete plays and a novel. The plays were Muhammad Yamin's "Ken Arok dan Ken Dedes," Armijn Pané's "Lukisan Masa" and "Njai Lenggang Kentjana," and Sanusi Pané's "Manusia Baru."13 The novel, Armijn Pane's, "Belenggu," was issued as a combination of three Pudjangga Baru issues when Balai Pustaka refused to print it on account of its controversial treatment of adultery. ${ }^{14}$ On the whole, however, prose fiction was relatively unimportant in Pudjangga Baru. Most Indonesian novels were then being published by Balai Pustaka, and the short story did not reach a position of real significance until the Japanese occupation. ${ }^{15}$

Pudjangga Baru counted over one hundred twenty-five people among its contributors--nearly as many as subscribed to it. of these, some twenty wrote for it frequently, and all of these worked at some stage on the journal's editorial staff. Their biographies show some striking similarities. ${ }^{16}$ Virtually all of

by Armijn Pané, "Djiwa-berdjiwa" was published in P.B. (VI, 7-8), January-February 1939. Among the most prominent of the Pudjangga Baru poets were M. R. Dajoh, Asmara Hadi (Abdul Hadi), Karim Halim, R. 0. Hanka, Intojo, Oemar Mandank, A. M. Daeng Mijala (A. M. Thahir), Mozasa (Mohammad Zain Saidi), Yogi (Abdul Rivai), Jusuf Sou'yb, J. E. Tatengkeng, S. Yudho, and Amir Hamzah.

12. P.B. (V, 10), April 1938; P.B. (IX, 3), September 1941. Takdir Alisjahbana's important essay on "Bahasa Indonesia" and Sanusi Pané's "Tjandrakirana dalam Kesusasteraan Dunia" appeared as special issues [P.B. (I, 5), November 1933; P.B. (I, II), May 1934].

13. P.B. (I, 7), January 1934; P.B. (IV, II), May 1937; P.B. (VIII, 5), November 1940 .

14. P.B. (VII, 10-11-12), April-May-June 1940; see further A. H. Johns, "Genesis of a Modern Literature," in McVey (ed.), Indonesia (New Haven: HRAF, 1963), pp. 418-419.

15. H. B. Jassin published two short stories in Pudjangga Baru. But these, together with extracts from novels, some fragments by Armijn Pane, and "Belenggu" were the only prose fiction which appeared. One literary form which did become very popular was a sort of rhythmic prose-poetry, often undisciplined and sentimental.

16. For biographical information on the Pudjangga Baru writers see Jassin, Pudjangga Baru; Takdir Alisjahbana (ed.), Puisi Baru (Djakarta: Pustaka Rakjat, 1951); W. A. Braasem, Moderne Indonesische Literatuur (Amsterdam: Van der Peet, 1954); Z. Usman, Kesusasteraan Baru Indonesia: dari Abdullah bin 
them went through the channels of the Dutch educational system and used Dutch as their main means of contact with Indonesians from other linguistic groups and with the world outside Indonesia. Most had attended primary school in their local town and then moved to a larger center such as Padang, Medan, Bandung, or Batavia for further education. Those who continued their studies beyond high school usually went to a teachers' college, studied law or medicine in Batavia, or perhaps took up engineering in Bandung; a few went to Europe for further work. When their formal education ended, most of them became teachers, journalists, publishers, or editors in government service at Balai Pustaka. In 1933, the year of Pudjangga Baru's founding, the average age of the writers who were to be its major contributors was about twenty-five. Most were Sumatrans: of the twenty-five most prolific writers, sixteen were from that island, three from Java, and six from elsewhere. But the similarities of the Pudjangga Baru writers derived not from the traditional Indonesian groupings of region, language, or religion but from the modernizing impact of Dutch colonialism in the twentieth century and resultant rise of a Western-educated urban intelligentsia, to which they belonged.

Abdulkadir Munsji sampai kepada Chairil Anwar (Djakarta: Gunung Agung, 1964); and the Ensiklopedia Indonesia. Frequent contributors to Pudjang ga Baru included Takdir Álisjahbana, Amir Hamzah, and Armij̄n and Sanusi Pané, whose backgrounds are described later. M. R. Dajoh, a Minahassan poet and novelist, was trained as a teacher in Ambon and Bandung; the poet A. M. Thahir (whose pseudonym was A. M. Daeng Mijala), had an unusual background in that he had only elementary schooling. He taught in a Muhammadijah school in his birthplace, Makassar, and worked on the side as a journalist and laborer. Mohammad Zain Saidi ("Mozasa"), an East Sumatran poet, was trained as a teacher of agriculture. Abdul Hadi (who usually went by the name Asmara Hadi but also used the pseudonyms Ipih, Ipih A. Hadi, Hadi Ratna, and H.R.) was born in Bengkulu, West Sumatra, and educated in Mulo schools in Bandung and Batavia and at the Taman Siswa Mulo school in Bandung. Intojo, also primarily a poet, was born in 'Tulungagung, East Java, attended headmasters' school at Bandung, and worked as a teacher. He wrote in Javanese as well as Indonesian, as did Poerbatjaraka, a notable contributor to Pudjangga Baru who differed from the rest in age (he was born in 1880), background (he was from the Solonese aristocracy), and training (he studied at the University of Leiden and became a professor). Demar Mandak, a Sumatran, taught in the Muhammadijah school system; Abdul Rivai and Suwandhi were also teachers, the latter working in Taman Siswa schools. The essayist Dr. Muhammad Amir was a European-trained psychiatrist. Soehardo Sastrasoewignja, Karim Halim, H. B. Jassin, and W. J. S. Poerwadarminta were all employed at Balai Pustaka. 
Not all those who contributed to the journal are seen 17 in retrospect, as members of the "Pudjangga Baru generation." 17 Sutan Sjahrir and Amir Sjarifuddin wrote for it but would not radical politician, has often been labelled as a Pudjangga Baru man though he never contributed to the magazine. Moreover, many writers intimately associated with Pudjangga Baru also worked for and published through Balai Pustaka, which was of quite a different intellectual and cultural climate. In large part, the impression of a distinctive Pudjangga Baru approach derives from the dominant influence of Takdir Alisjahbana's personality, which did much to determine the spirit of the journal and the historical image of that generation of writers. Those who somehow shared the style have been seen as Pudjangga Baru men, and those whose characters stood apart were not. ${ }^{1}$

The appearance of Pudjangga Baru was not isolated from the political and national consciousness of the time. On the contrary, the connection between art and life was stressed. In the preface to the first number of the journal, Professor R. A. Hoesein Djajadiningrat wrote that every group must work for the progress of the Indonesian spirit (semangat Indonesia), and that literature and language could not be left out of this process of

17. It has been customary to describe the development of modern Indonesian literature by using chronological categories, often called angkatan (generation), as in Angkatan Duapuluhan, to refer to the writers of the twenties, or Angkatan ' 45 for the writers of the revolutionary and immediate post-war period. Recently writers have been questioning the validity of this convenient but rather forced classification, emphasizing the continuities and similarities in the literature. See particularly the article by Ajip Rossidhy on "The contribution of the most recent generation of Indonesian writers to to development of Indonesian literature," in Kapankah Kesusasteraan Indonesia Lahir? (Djakarta: Bhratara, 1964), pD. 29-50; Pramudya Ananta Tur, "Tentang Angkatan," Indonesia (Djakarta) (III, 12), December 1952, Pp. 19-23; and a review of Teeuw's Pokok dan Tokoh by "B.S.," Indonesia (Djakarta) (V, 1-2), January-February 1954, PP. 75-78.

18. Thus Armijn Pané commented that what distinguished Pudjangga Baru from other trends was a certain attitude towards life and culture rather than a single literary style. See his Korte Overzicht van de moderne Indonesische literatuur (Djakarta: Balai Pustaka, 1949), p. 33; and the introduction to his collection of poems, Gamelan Djiwa (Djakarta: Dep. P. P. dan K., 1960), pp. 7-8; and Teeuw, Pokok dan Tokoh (I), PP. $53-54$. 
national development. ${ }^{19}$ The editors themselves affirmed their loyalty and devotion to semangat Indonesia, and undertook to tend this spirit in order that it might give form to all the "beautiful and noble emotions and thoughts contained in the hearts of our people." 20

Yet Pudjangga Baru was not concerned with the majority of the Indonesian people. It did not address itself to the common people, and it seldom discussed the concrete social or political problems they faced. It was rather an attempt to write and speak for the intellectuals, in particular the "modernizing" intelligentsia. Consequently, although it was not editorially intolerant and did not demand that contributors come from any particular background or express any special viewpoint, its writings were largely restricted to the concerns of that rather narrow milieu.

The dominant problem faced by the intellectuals in colonial Indonesia, and thus the central theme of Pudjangga Baru's writings, was that of ambivalence toward the European government and its culture and to the indigenous society and its values. The Pudjangga Baru men considered themselves nationalists, but rejection of the Dutch claims to dominion over the Indies by no means required them to reject European culture. Indeed, many of the politically most radical nationalists were also culturally the most Westernized. For many intellectuals, total rejection was no longer possible, while full acceptance of the West was no less difficult. The Dutch themselves tended to lose their cultural "purity" in the Indies. It was hard enough for them to "keep up" with Europe; it was immeasurably harder for non-Europeans to do so. ${ }^{21}$ Most Indonesian concepts of Western intellectual life were gleaned from indirect and fragmentary sources: books, films, passing acquaintance with Dutchmen. A lack of balance, perspective, and depth was inevitable. It was easier for those Indonesians who had studied in Europe and so were able to observe and participate in the social matrix of Western cultural life; yet a return to Indonesia left the center of their intellectual world thousands of miles away. They tried to keep up by reading, but did not have the financial resources, the materials, or the leisure to do

19. P.B. (I, 1), July 1933, P. 1. Similarly, the prospectus for Pudjangga Baru asserted that it sought to make cultural development more relevant to "the desires of the times and the new situation in Indonesian society" (quoted in Siregar, Sedjarah, p. 77).

20. P.B. (I, I), July 1933, p. I.

21. For a discussion, see W. F. Wertheim, Indonesian Society in

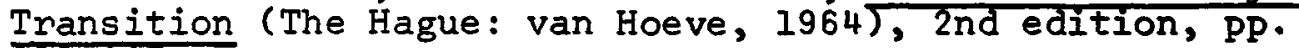
296-297. 
this effectively. The Indies environment claimed most of their attention; a certain "provincialism" was the result, many European elements in the life of the intelligentsia remaining derivative and imperfectly absorbed.

Something of the sort was also true of the intellectuals' relation to the indigenous cultures of the archipelago. The Indonesian intelligentsia of the 1930s was small, isolated, idealistic, and enthusiastic, very aware that it had an Indonesian identity yet unsure what, precisely, this involved. For many of those Indonesians who had spent most of their adult life in Dutch schools and offices, knowledge of their own society was based on their reading of Dutch books, and the Indonesian cultures they wished to reconcile with the West tended to be academic abstractions rather than living worlds.

Some insight into the problems faced by the intellectuals of the time can be seen in their reaction to contact with the liberal Dutch writer Edgar du Perron, who had a considerable impact on some of them during his stay in Java in the 1930s.22 Suwarsih Djojopuspito recalled him telling the circle with which he had become associated that: "Your point of view is not yet universal, your reading is not yet universal, and your movement is still romantic nationalism, but you are good people. . . "

22. Edgar du Perron was born in Batavia in 1899 but left for Europe at an early age. A socialist, not given to compromise, he found himself ill at ease in the pre-war Netherlands and returned to Indonesia in 1936. There, finding little in common with the Dutch colonials, he turned to the liberal Dutch minority and the Indonesian intelligentsia. Among the Indonesian intellectuals associated with him were Suwarsih Djojopuspito and her husband; her sister and brother-in-law A. K. Pringgodigdo; Sujitno Mangoenkoesoemo; and M. R. Dajoh. This group was oriented towards Europe and was probably less provincial in terms of Western culture than most other intellectual circles in the colony. E. du Perron, Indies Memorandum (Amsterdam: 1946); J. M: van der Kroef, "The Colonial Novel in Indonesia," Comparative Literature $(X, 3), 1958$, pp. $223-$ 224 ; Braasem, Moderne Indonesische Literatuur, pp. 35-36; A. Deprez, E. du Perron, 189971940; zijn leven en zijn werk (Brussels: Manteau, 1960), PP. 181-234; J. H.W. Veenstra, D'Artagnan tegen Jan Fusilier: E. du Perron als Indisch polemist (Amsterdam: van Oorschot, 1962); R. Nieuwenhuys, "The Tropical Decor," Delta (III, 3), Autumn 1960, pp. 65-69, for a discussion of du Perron's role in the development of Indonesian literature. I am also indebted to Beb Vuyk, who discussed du Perron with me at Loenen, the Netherlands, on February 4, 1966.

23. Suwarsih Djojopuspito, "Du Perron dan pengaruhnja kepada kaum intelek Indonesia 1936-1939," P.B. (XIII, I-2), July 1951, p. 30. Suwarsih Djojopuspito was born in Bogor in 1912, 
He contrasted their virtues with the pride, dishonesty, and sterility of the Dutch, and set about to broaden their outlook. He used to visit them--a rare event at a time when few Dutchmen went to Indonesian houses--and to argue with them, telling them stories of the intellectual circles of Europe in which he moved, of Paris and Brussels and Amsterdam, and of the people he knew: Menno ter Braak, Jan and Annie Romein, Henriette Roland Holst van der Schalk, Jef Last, Andre Gide, Malraux. Suwarsih remembered: "The world became close, literature became accessible... . " 24

For all his stress on Western cultural life, du Perron was disturbed by the Indonesian intellectuals' lack of interest in their own past, in the traditional culture which he himself found so interesting. Suwarsih wrote:

He was not able to understand why we lived solely for politics, we read only politics, Marxism and history and economics, casting literature to the side. . . Indeed, it was only the Western world which claimed our attention, but even in that we were not universal; in general whatever was socialist or Marxist in character, that we studied, and whatever happened in Soviet Russia, that we paid attention to at that time.

Probably at that time there were only a few dozen people who were not romantic but feudal nationalists. . the sort who played the gamelan, danced the ${ }_{25}{ }_{5}$ oget, on staged performances. of wajang orang. .

The Indonesians could themselves be painfully conscious of the derived and imperfect nature of their contact with Western modernity. Sutan Sjahrir, who criticized not the Westernization of the intellectuals but the superficiality of their conversion to the West, belabored this weakness unsparingly. He disposed swiftly of the suggestion that there was a cultural renaissance in Indonesia, particularly in reference to the work of Pudjangga Baru:

There is no thought, no form, no sound, and what is worse, there is not yet enough earnestness and

graduated from the Dutch Teachers' College in 1931, and taught from 1931 to 1945. She published Buiten het Gareel, a novel in Dutch (after a Sundanese version had been rejected by Balai Pustaka), in 1940. See Johns, "Genesis of a Modern Literature," p. 548, note 12 .

24. P.B. (XIII, 1-2); July 1951, P. 33 .

25. Ibid., p. 32 . 
integrity among us. There is still only unsavoury counterfeit. . . there is also no avowal of life's major problems, and as a result there is again a lack of real knowledge of life among us. A boy of perhaps seventeen or eighteen years in Europe . . . knows something more about life than our Indonesian intellectuals and scholars. ${ }^{26}$

If the Indonesian intellectuals was not as "worldly" as a European youth it was because his world was not the same. Even so, his was a world that was moving closer to the Western one, as European ideas became increasingly influential. Concepts of social humanism, of the rights and dignity of individuals and nation states, Marxism, democratic political theory, and the idea of progress changed the contours of the intellectual world in Indonesia as they did in other countries of Southeast Asia. That these new ideas were heavily political is scarcely surprising, for the development and exposition of political ideology was not only stimulated by the social need for national solidarity but also by the individual intellectual's search for a formulated and meaningful identity and a sense of security in a changing cultural landscape. ${ }^{27}$

At the same time, some modernizing intellectuals endeavored to revive and adapt traditional values. This was not simply a reaction to the inroads of Western ways, although the Western cultural threat was a key stimulant. It also represented the recognition of the continued vitality of tradition. Indigenous cultures sustained their identity--particularly in the Javanese principalities of Jogjakarta and Surakarta--and continued to have some meaning even to an inteliligentsia far removed physically and mentally from the cultural heartlands. ${ }^{28}$ Under the auspices of the cultural nationalists, European techniques of organization and communication were brought into the service of tradition, and attempts were made to adapt the form and content of Indonesia's heritage to a changing world. Thus, Javanese cultural congresses were held; the teaching of classical dance was extended to public schools as well as the kraton; associations for the promotion of indigenous art forms were established, and

26. Sjahrir, Out of Exile, translated and introduced by Charles Wolf (New York: John Day, 1949), Pp. 4-5.

27. For a discussion, see D. E. Apter, Ideology and Discontent (New York: Free Press, 1964), Pp. 18-33.

28. G. J. Resink, "Java 1900-1930," paper prepared for the Java Seminar organized by the Institute of Social Studies, The Hague, 1959 (mimeo), pp. 20-23; Selosoemardjan, "Some Social and Cultural Implications of Indonesia's Planned and Unplanned Development," The Review of Politics (XXV, 1), January 1963 , pp. 65-66. 
so on. ${ }^{29}$ The Taman Siswa school system contributed notably to the philosophical development and spread of this cultural nationalist approach. Some cooperation was also obtained from the Indies authorities, who understandably preferred cultural to political manifestations of the Indonesian spirit. ${ }^{30}$

Though the cultural nationalists were privately interested in political questions and were drawn to Western political concepts, there was something of a strain between them and nationalist political activists, centering about the question of militancy in the anti-colonial cause. Pudjangga Baru reflected the position of the cultural nationalists in its studied neutrality on political affairs. Its quietude was understandable, for it ensured that the journal could continue publishing and that its government-employed contributors would retain their posts. But it has not always been forgiven by the more militant of the Indonesian intellectuals. Thus, the Marxist critic Bakri Siregar charged Pudjangga Baru with lacking a clear political perspective and separating itself from the nationalist struggle;

29. For discussions of some of the cultural nationalist efforts, see Resink, "Java 1900-1930," pp. 20-21; J. S. Furnivall, Netherlands India: A Study of Plural Economy (Cambridge: University Press, 1944), P. 425; Mantle Hood, "The Enduring Tradition: Music and Theater in Java and Bali," in R. McVey (ed.), Indonesia, p. 459. Pudjangga Baru gave publicity to such endeavors in its irregularly appearing "Kroniek." See, for example, P.B. (III), pp. 158-159; (IV), PP. $52,66,83-84,116$; (VIII), P. 184.

30. Thus in 1922 the Java Institute was founded, which was destined to become the center for formal studies on Javanese culture; while an Oriental division of the A.M.S. (senior secondary school) at Solo educated young people who were later to be influential in Indonesia's cultural development. Some examples of Dutch thinking on the matter of cultural vs. political nationalism may be found in the writings of $\mathrm{B}$. J. 0 . Schrieke and $\mathrm{Ch}$. 0 . van der Plas. In Schrieke's analysis, the political nationalists tended to want assimilation with the Europeans and neglected or were hostile to indigenous culture, while the cultural nationalists opposed all that might estrange the Indonesians from their cultural heritage. Van der Plas drew a line between a "truly Indonesian" nationalism, comparable to Schrieke's cultural nationalism, and a rather destructive European-style nationalism. The former was typified by the teachings of Ki Hadjar Dewantara's Taman Siswa or Dr. Sutomo's Study Club, philosophies which Van der Plas regarded as in accord with the Indonesian ideal of harmony. See B. J. O. Schrieke, "Native Society in the Transformation Period," in his The Effect of Western Influences on Native Civilizations in the Malay Archipelago, pp. 244245; C. van der Plas, Nationalism in the Netherlands East Indies (New York: Institute of Pacific Relations, I942), Pp. I-12. 
it had "insufficient political awareness." 31 While he acknowledged the contributions of writers such as Armijn Pane and Takdir Alisjahbana to Indonesia's cultural modernization, he was unhappy with their political stance and censured Armijn Pané, in particular, for a lack of resolution in his work, which focussed on the doubts and anxieties of the intelligentsia. ${ }^{32}$

Not all the Pudjangga Baru writers eschewed political fervour in their contributions to the magazine. Asmara Hadi, a frequent contributor of poetry, published nationalist and radical verse, including a sonnet to Rosa Luxembourg. ${ }^{3}$ Another Pudjangga Baru poet of outspoken political enthusiasm was Ali Hasjmy. ${ }^{34}$ Some directly political prose also appeared, most notably an article by "Candide" on "Kemerdekaan" 35 and some notes on Fascism by Amir Sjarifuddin. ${ }^{36}$ But these were exceptions. Most of the Pudjangga Baru contributors restricted their patrjotic expression to the lyrical celebration of the beauty of their islands and to essays which attempted to formulate a culture for the Indonesian nation of the future. ${ }^{3} 7$

A related and somewhat academic unconcern characterized Pudjangga Baru's attitude to Indonesian social and economic

31. Siregar, Sedjarah Sastra Indonesia Modern, p. 83.

32. Ibid., p. 84. Usman Effendi, Sasterawan-sasterawan Indonesia, pP. 51-52, also finds Armijn Pané's approach weak and irresolute.

33. This was one of seven poems appearing in the July 1937 number of Pudjangga Baru. See P.B. (V, I), July 1937, Pp. 6-9; and also Jassin, Pudjangga Baru, Pp. 181-182; Alisjahbana, Puisi Baru, PP. 111-112. They were signed "H.R.," the pseudonym under which Asmara Hadi published his most outspokenly nationalist poetry. The initials derived from Hadi's own name and that of his wife, Ratna, who was Sukarno's adopted daughter. See Cindy Adams, Sukarno: An Autobiography (Indianapolis: Bobbs-Merrill, 1965), pp. 146-147, 183-184.

34. See for example, "Tanah Iboekoe," P.B., Nomor Peringatan $1933-1938, \mathrm{p} .31$.

35. P.B. (V, I), July 1937, PP. 2-6.

36. P.B. (VI, 4-5-6), October-November-December 1938, PP. 66-70. occasionally one could also find political comment in such irregularly appearing features as "World Cycle," which published, for example, some political material by Dr. M. Amir (see P.B. $(V, 6)$, December 1937, Pp. 125-126).

37. See A. Pané, Konte Overzicht van de moderne Indonesische literatuur, p. 33 . 
problems. Writers who elsewhere expressed deep social concern did not display their involvement on the pages of that journal. ${ }^{38}$ Most showed more intellectual interest than commitment in their discussion of social questions, which remained on a general and non-prescriptive plane. Some subjects were given specific attention, most notably the role of women and youth, ${ }^{39}$ and a good deal of attention was paid to the evolution of a philosophy of education. 40 These, however, remained minor elements in Pudjangga Baru's main theme, which was the creation of a new Indonesian culture out of the interaction of East and West.

38. The poet M. R. Dajoh, for example, was deeply concerned with the difficulties faced by the Indonesian masses, yet published few poems on this subject in Pudjangga Baru. Elsewhere he had issued such intense and bitter social verse as "Pekerdjaan Anak," "Orang Tani dan Saudagar," and "Perempuan Menumbuk Padi," but his major work in Pudjangga Baru was on Minahassan culture. See du Perron, Indies Memorandum, pp. 89-90; Jassin, Pudjangga Baru, pp. 157-162; Alisjahbana, Puisi Baru, pp. 43-48. A few rather political poems--including the quite extreme "Persatuan Partij-Partij Indonesia" did appear in Pudjangga Baru--see P.B. (VII, 7), January 1940, Pp. 135-136; P.B. (IX, 4), October 1941, PP. 126-127; P.B. (VII, 12), June 1939, pp. 211-212.

39. The April 1938 issue of Pudjangga Baru was dedicated to the feminist Raden Adjeng Kartini. Armijn Pané translated Kartini's writings into Indonesian and wrote about her in P.B. (III, 10), April 1935, Pp. 298-310. The feminist leader Maria Ulfah Santoso published an article on the marriage laws in P.B. (VII, 8-9), February-March 1940, PP. 183-199. Articles on women and Iiterature appearing in Pudjangga Baru included ones by Takdir Alisjahbana in P.B. (VIII, 7 and 8 ), January and February 1941, Pp. 154-164, 195-206; and by Soripada in P.B. (I, 9), March 1934, Pp. 136-140. For essays on the youth movement, see P.B. (IV, I), July 1936, Pp.6-12; P.B. (VIII, 8 and 9), February and March 1941, pp. 185-194, 219224.

40. Pudjangga Baru leaders were active in the lively discussion over the proper road for Indonesian education in the 1937 All-Indonesian Congress of Education. For the arguments on educational philosophy, see Achdiat Karta Mihardja, Polemik Kebudajaan (Djakarta: Balai Pustaka, 1950), pp. 35-120; Takdir Alisjahbana, Indonesia in the Modern World, trans. B. Anderson (New Delhi: Congress for Cultural Freedom, 1961), PP. 143-147; P.B. (III, 4 to 12), October 1935 to June 1936, passim; P.B. (VII), 1939, passim. For further comments on education, see P.B. (II, I), July 1934, PP. 10-20; P.B. (III, 9 and 10), March and April 1936, PP. 237-241, 267-275; P.B. (IV, 9 and 10), March and April 1937, pp. 117-121, 138-141; P.B. $(V, 8)$, February 1938, PP. 174-186; P.B. (IX, 3), September 1941, pp. 71-78. 
In its efforts to formulate this new, unified culture, Pudjangga Baru did not promote any particular religious view as a base. Takdir, the chief editor, was essentially secular in his attitude to religion, while the orientation of the more prominent contributors ranged from the orthodox Islam of A. Hasjmy, Anwar Rashid, and Rifai Ali to the more personal Muslim interpretation of Amir Hamzah, the Christianity of J. E. Tatengkeng and Professor Moelia, and the Balinese Hinduism of I.G.N.P. Tisna. ${ }^{41}$ The main dichotomy was rather between those who emphasized the contributions the west could make to Indonesian culture and those who sought their inspiration in "Asian" values.

Takdir Alisjahbana had a clearly delineated vision of the world's cultural and social development and of Indonesia's place in it. 42 He felt the evolutionary stages of European civilization to be relevant to Indonesian social change: the monastery, castle, and peasant's hut of the Middle Ages represented a stage comparable to the "static and peaceful" Indonesian society which had been destroyed by modernization. The new Indonesians must create a new society, and this could only be done, in his eyes, by the adoption of Western techniques and dynamic European attitudes. ${ }^{3}$ To his mind, the future of Indonesia demanded that

41. Very little attention was devoted to religion as such: there were some reviews of Islamic books, articles on Islam in literature, comments on Islamic law in relation to modern society, and an essay on the Lahore Ahmadijah by Ismail Djamil. See P.B. ( $I, 3)$, September 1933, PP. 65-67; P.B. (VIII, 11), May 1941, pp. 312-314; P.B. (IX, 6-7-8), February 1942, pp. 172-182. Johns, "Genesis of a Modern Literature," p. 416, points out the relative absence of Islam as a consoling or mediating force in the social conflict themes of early Indonesian novels.

42. Sutan Takdir Alisjahbana was born in 1908 in the Tapanuli region of North Sumatra. He attended Dutch-language elementary school (H.I.S.) at Bengkulu, primary teachers' school (H.I.K.) at Bukittinggi, and teachers' training college (H.K.S.) at Bandung. He then worked for a headmaster's certificate at Batavia and also studied law from 1937 to 1941 . From 1928 to 1930 he taught in Palembang, and from 1930 to 1942 he worked in Balai Pustaka, first as editor of the magazine Pandji Pustaka and later as literary editor and author. In 1933 he established the private publishing house Pustaka Rakjat, which issued Pudjangga Baru. He wrote five novels, a volume of poetry, and numerous essays and translations.

43. See Takdir Alisjahbana, Indonesia in the Modern World, pp. I$27,139-194$ and passim; also his "Traditional and Modern Values in Our Culture," in Congress for Cultural Freedom, Cultural Freedom in Asia (Rutland, Vt.: Tuttle, 1956), Pp. 38ff.;G. Rasid, Ditengah-tengah. Perdjuangan Kebudajaan 
country's taking its place in the world, breaking down the barriers of isolation and provincialism to participate in international culture. This world culture as conceived by Takdir was elitist-the high culture of Goethe and Tagore, Verlaine and Krishnamurti, Pirandello and Lin Yu-tang. Such blindness to elements outside the aesthetic elite was common to Takdir's day, being shared by such eminent Dutch scholars as Huizinga, but in Indonesia's rapidly changing society it appears as an even greater shortcoming than it does in the European writings of the time. ${ }^{44}$

Armijn Pane, the second founder of Pudjangga Baru, has been described as "one hundred per cent Western," in contrast to the "universality" of Takdir. ${ }^{45}$ His education was more completely

Indonesia (Djakarta: Pustaka Rakjat, 1949) (an account of ten interviews with Takdir on cultural affairs); and W. le Febre, Taman Siswa (Djakarta: Balai Pustaka, 1952), pp. 41-55.

44. This orientation toward cosmopolitan high culture is generally apparent in Pudjangga Baru, which ignored the vigorous development of Indonesian urban folk culture in the 1930s. This flowering was notably displayed in the komedie stambul theatre and the popular spread of krontjong songs. The increasing penetration of radio and films into all levels of Indonesian life also marked a major cultural change in the pre-war period; a fledgling film industry was already developing at that time. Armijn Pane did write on mass media, but by and large the leisure activities of the masses were not really regarded as "cultural" and so were ignored. So were some new forms of Indonesian elite culture, notably the modern Western-style drama, or sandiwara, which reached the peak of its development in the late 'thirties, and painting, which was experiencing considerable development then under $S$. Soedjojono and Affandie. See A. Pané, "Produksi Film Tjerita di Indonesia: Perkembangannja Sebagai Alat Masjarakat," Indonesia (Djakarta) (IV, 1-2), January-February 1953, pp. 1033; F. E. Enre, Perkembangan Puisi Indonesia dalam Masa Dua Puluhan (Djakarta: Gunung Agung, 1965), Pp. 61-67; Claire Holt, Art in Indonesia (Ithaca: Connell, 1967), pp. 194-198; 'Seniman', "Asal-mula Kerontjong," Gema Suasana (II), November 1938, pp. 658-662; Gajus Siagian, "Perkembangan Film di Indonesia," Indonesië (VII), 1953-1954, pp. 221-224. The only attention Pudjangga Baru allotted a painter was awarded to Mas Pirngadie; see P.B. (II, 6), December 1934, pp. 161-166; P.B. (II, 8), February 1935, pp. 236-240; (III, 10), April 1936, PP. 263-265; P.B. (VIII, I1), May 1941, p. 315 .

45. Effendi, Sasterawan-sasterawan Indonesia, pp. 44, 50. Like Takdir Alisjahbana, Armijn Pané was born in Tapanuli in 1908. He attended H.I.S. at Padang Sidempuan and Tandjung Balai and then went to the European schools at Sibolga and Bukittinggi. In 1923 he started at the Stovia medical school in Batavia and in 1927 transferred to the Nias medical college in Surabaja. From there, concluding that his heart lay with languages and 
in the Western style for, while the other core leaders of Pudjangga Baru--Takdir, Amir Hamzah, and his own brother Sanusi--attended H.I.S., where the language was Dutch but the students and atmosphere Indonesian, Armijn Pané went to Europese Lagere School, which was run by and largely for the Europeans. But in spite of his extreme Western orientation, Armijn Pane's work has worn better than that of most of his contemporaries, perhaps because of the awareness of complexities and contradictions, the refusal to provide easy solutions, and the disregard for the conventional Indonesian moralities that made him a controversial figure in his time.

Sanusi Pane leaned, at least outwardly, to the opposite cultural pole from his brother, for he was deeply affected by two years spent in India, and his writings stressed the spiritual truth, enlightenment, and harmony of "Asian" values as contrasted with the emphasis on rationality, individuality, and materialism in the works of the Westernizers. The contrast between the "Asian" and "Western" approaches was most vividly illustrated in a famous controversy carried on between Sanusi Pané and Takdir in the columns of Pudjangga Baru and the newspaper Suara Umum. Their argument revolved around the definition of the word "Indonesia": Takdir maintained that until the end of the nineteenth century one could speak only of a "pre-Indonesia," while Sanusi, feeling this was a rejection of the Indonesian past and identity, disagreed. In the course of this debate Sanusi Pane made the comparison--since then often quoted--between the West as Faust, abandoning his soul for material authority, and the East, like Ardjuna, seeking spiritual truth. ${ }^{46}$

Nonetheless, it would be a mistake to underestimate the role played by Western culture in the development of Sanusi's thought. German romanticism influenced him as well as the teachings of Tagore, and he acknowledged Western technology and its achievements even while seeking peace in Asian religion. As many other Indonesian intellectuals of the pre-war period who sought to reconcile two cultural worlds, he became an adherent of theosophy. ${ }^{47}$ Absorbed in the search for a union of East and

literature rather than medicine, he went to the A.M.S. in Solo, where he graduated from the literary division in 1931. He worked as a journalist in Batavia and Surabaja and taught languages and history at nationalist schools in Kediri and Batavia before taking a job as editor at Balai Pustaka in 1936. He published the novel "Belenggu" and a volume of verse "Djiwa-berdjiwa" in Pudjangga Baru, as well as two plays and a number of short stories and essays.

46. For the arguments, see Achdiat Karta Mihardja, Polemik Kebudajaan, Pp. 12-33.

47. J. U. Nasution, Pudjangga Sanusi Pané (Djakarta: 1963), pp. 103, 106. The growth of theosophy in pre-war Indonesia is 
West, the spiritual and the material, the inner and outer worlds, ${ }^{48}$ he composed poetry and plays that were preoccupied with philosophical issues. ${ }^{4}$

The fourth member of Pudjangga Baru's core group, Amir Hamzah, was the best of the colonial Indonesian poets; his verse did not fade, and he influenced later writers. In contrast to the pan-Asian and Westernizing emphasis of his colleagues, he was concerned philosophically with the assimilation of Indonesia's diverse cultures and beliefs. As a member of the North Sumatran aristocracy, he had received a considerable education in Malay literature and history before he came to Java, ${ }^{5}$ but most of his

a most interesting example of the interaction between traditional and Western values among the intelligentsia. Its teachings, drawing heavily on Indian thought, stress salvation by intuitive, esoteric knowledge and affirm the unity of God and the universal brotherhood of man. The mysticism of theosophy appealed to the Indonesians as a major element in Javanese culture and an important aspect of Indonesian Islam. Takdir Alisjahbana, commenting on its popularity, considered it the result of an attempt by Indonesians to maintain traditional values in the face of "the anarchy, the contradictions, the confusion, and the materialism of the modern world." See Robert van Niel, The Emergence of the Modern Indonesian Elite (The Hague: van Hoeve, 1960), PP. 53, 63, 173; Takdir Alisjahbana, Indonesia in the Modern World, p. 142; Resink, "Java 1900-1930," PP. 20-21.

48. Jassin, Pudjangga Baru, p. 267.

49. Poetry by Sanusi Pané has been collected in Jassin, Pudjangga Baru, Pp. 269-286; Alisjahbana, Puisi Baru, pp. 120-128; and is discussed by Ajip Rossidhy, "Sadjak-sadjak Sanusi Pané," Indonesia (Djakarta)(VII, 4), April 1956, pp. 152-160.

50. Amir Hamzah was born in Langkat, North Sumatra, in 1910; he had the title Pangeran Indra Putra. He was educated at the H.I.S. in Tandjungpura, at the Mulo in Medan and Batavia, and in the division of literature and Asian culture of the Solo A.M.S. He studied law in Batavia, but family obligations, including an arranged marriage, forced his return to Sumatra. He was killed there in the Social Revolution--an uprising against the local aristocracy--which took place in March 1946. See Effendi, Sasterawan-sasterawan Indonesia, pp. 22-28, 44$52 ; \mathrm{H}$. B. Jassin (ed. and introduction), Amir Hamzah: Radja Penjair Pudjangga Baru (Djakarta: Gunung Agung, 1962), Pp. I720 and passim; A. H. Johns, "Amir Hamzah: Malay Prince, Indonesian Poet," in J. Bastin and R. Roolvink (eds.), Malayan and Indonesian Studies (Oxford: Clarendon Press, 1964), pp. 303-319; Usman, Kesusasteraan Baru Indonesia, pp. 235-261. 
writing was done in the central island, and his schooling there encouraged the assimilation of Javanese influence into his verse. ${ }^{1}$ His later work was intensely religious, reflecting a very personal Islam, in which Christian and Hindu-Javanese elements could also be discerned. At its best, Amir Hamzah's poetry integrated these varied traditions into a highly original and powerful verse.

However they saw Indonesia's cultural future--in terms of increased Westernization, Asianism, or the revitalization of the domestic heritage--the Pudjangga Baru men were unanimous in their determination that there should be a single national culture. Central to this project was the creation and spread of a usable national language, and Pudjangga Baru's editors--Takdir Alisjahbana and Sanusi Pané in particular--played an important role in achieving this. 52 The other main outlet for Indonesian writings, Balai

51. For a discussion, see Johns, "Genesis of a Modern Literature," pp. 421-422; Johns, "Amir Hamzah," pp. 309-312, 316. Other Pudjangga Baru contributors who showed concern for the revitalization of Indonesia's traditional cultures included Poerbatjaraka, who wrote on aspects of Javanese and Malay culture and was involved in the "pre-Indonesia/Indonesia" dispute. See P.B. (IV, I), July 1936, Pp. 14-16; P.B. (VII, 7), January 1940, PP. 128-132; P.B. (VIII, II), May 1941, PP. 287-296; and Mihardja, Polemik Kebudajaan, pp. 30-31. S: Sastrasoewignja contributed a nine-part series on modernizing the wajang (P.B. (II), 1934-1935) and wrote on Indonesian linguistics and modern Javanese writing ( $P$.B. ( $I, 3$ and 4 ), September and October 1933, Pp. 76-79; 10 $9-1 \overline{1} 1$; P.B. (I, 10), April 1934, Pp. 307-312; P.B. $(V, 2)$, August 1937, PP. 45-51). Much less attention was devoted to Malay culture than to Javanese in spite of the predominance of Sumatrans in the Pudjangga Baru group; the main contributors on this subject were Sanusi Pane and Amir Hamzah, although Hoesein Djajadiningrat published a three-part essay on the hidden meanings of the Malay pantun (P.B. (I, 6), December 1933, Pp. 193-198; P.B. $(I, 8)$, February I934, PP. 246-248; P.B. (I, 9), March 1934, PP. 275-282). Finally, M. R. Dajoh devoted attention to the culture of Minahassa in articles appearing in Pudjangga Baru in 1940 and 1941 .

52. Teeuw, Pokok dan Tokoh, I, PP. 27-43; S. T. Alisjahbana, "Le développement de la langue et de la litterature Indonésienne," Journal of World History (II, 3), 1954-1955, PP. 682-703. This article has much the same content as Indonesia in the Modern World, pp. 52-73, 81-99, but it adds a useful bibliography, particularly of Dutch materials. Many of Takdir's articles on language are reprinted in his Dari Perdjuangan dan Pertumbuhan Bahasa Indonesia (Djakarta: Pustaka Rakjat, 1957). In November 1933 he published a grammar of Bahasa Indonesia as a special issue of Pudjangga Baru, which was of considerable value as a pioneering study. 
Pustaka, encouraged the use of Malay but also published a great deal in the regional languages and Dutch; Pudjangga Baru published almost exclusively in Indonesian, in spite of the fact that this limited its clientele. The journal devoted much attention to the analysis of Bahasa Indonesia and the discussion of its future, while the creative and critical writing it published set new standards for the language and revealed its flexibility and efficiency.

The transformation of Malay into a Bahasa Indonesia capable of expressing complex situations and modern ideas was no small task, the more so as Dutch and the regional languages were firmly established as literary vehicles and many Indonesian writers did their early work in Dutch. Few observers of Bahasa Indonesia's early growth took the language seriously. Bousquet described it as "that preposterous language Malay," and even in 1945 a Dutch authority could refer to it as "a mere auxiliary language, only fit for communications of a simple and concrete kind." 53 Pudjangga Baru did much to see that the language was accepted by the Indonesian intellectuals. It initiated the first congress on Bahasa Indonesia in 1938, and Takdir Alisjahbana, Amir Sjarifuddin, Adinegoro, and Sanusi Pané gave papers there. ${ }^{4}$ Pudjangga Baru was not above criticism on the language score-some declared that what it published was Dutch written with an Indonesian vocabulary ${ }^{5}$--but it did play a major role in that central achievement of pre-war cultural nationalism, the evolution of a national language.

The literary contribution of Pudjangga Baru is, in retrospect, less considerable. Most of the colonial literature, both poetry and prose, has faded away. That it should not have endured is understandable, for the early Indonesian writers were in a situation which made really high level writing unlikely. They were, as we have noted, producing in something of a vacuum; their models and standards were imported, not integrated with the realities of the writers' experiences. They lacked a well

53. G. H. Bousquet, A French View of the Netherlands Indies (London: Oxford, 1940), p. 79; Van Helsdingen and Hoogenberk, Mission Interrupted: The Dutch in the East Indies and Their Work in the XXth Century (Amsterdam: Elsevier, 1945), p. 78.

54. Siregar, Sedjarah Sastra Indonesia Modern, p. 83; A. Teeuw, "Poedjangga Baroe en de Bahasa Indonesia," Orientatie (No. 13), October 1948, pp. 24-28.

55. Armijn Pane's writing, for example, has been described as easy for a Dutchman to read but difficult for an Indonesian because of the extreme "Dutchness" of its style. See Effendi, Sasterawan-sasterawan Indonesia, p. 43; Jassin, Pudjangga Baru, PP. 13-15. 
developed and pertinent body of literary theory, they lacked indigenous classics of recognized greatness to act as standards and challenges, and they lacked a well informed and respected critical public--all elements of fundamental importance to a literary tradition. The significance of Pudjangga Baru for Indonesian literature lies largely in the fact that it attempted to remedy these deficiencies, to formulate a theory of art, to create serious literary works, and to provide a forum for critical discussion. ${ }^{56}$

The aesthetic theories of Pudjangga Baru were romantic and betrayed the dominant influence of the Dutch "Tachtigers"--the Generation of the $1880 \mathrm{~s}$. Historical circumstance played a role in determining this, for the schoolbooks from which the Pudjangga Baru men first made their acquaintance with European literature gave a key place to the Tachtigers as a revolutionary wave in Dutch literary development. 57 This was probably not the sole reason for the appeal of thein romanticism, however. The Dutch group itself had been influenced by the English romantics Keats, Shelley, and Byron (whom the Pudjangga Baru writers in turn were to admire); and it has been noted that these poets "lived through the crucial period in which the rise both of democracy and of industry was effecting qualitative changes in society: changes which by their nature were felt in a personal and general way."58 Comparable changes were taking place in Indonesia during the 'twenties and 'thirties, and the Pudjangga Baru writers found themselves similarly involved in the crisis of social transformation. The present was often painful and confusing, and it was tempting to try to escape from its reality, turning towards the glories of Indonesia's past "Golden Age," to immersion in the physical beauty of the islands, or to the idealization of a future Indonesia--all typically romantic themes.

The young writers and poets who followed Pudjangga Baru were often scathing in their criticisms of the periodical and

56. For some of these efforts, see Dr. M. Amir on the soul of the writer, P. B., Nomor Peringatan 1933-1938 (1938), Pp. 61-64; W. J. S. Poerwadarminta on understanding art, P.B. (V, 7 and 8), January and February 1938, pp. 152-156, 18 $\overline{7-19} 1$; Soewandhie on seeking new form, P.B. (I, 1I), May 1934, Pp. 332-336; J. E. Tatengkeng on criticism and personal standards, P.B., (VI, 10), April 1939, Pp. 157-161.

57. Jassin, Pudjangga Baru, pp. 29-34; Teeuw, Pokok dan Tokoh, I, p. 36 . See also Braasem, Moderne Indonesische Literatuur, p. 22 ; W. A. Braasem, "Doorbraak uit oude bedding," Orientatie (No. 44), 1952, p. 422.

58. R. Williams, Culture and Society 1780-1950 (New York: HarperRow, 1961), p. 49 . 
flatly repudiated its more romantic attitudes. Rivai Apin called Takdir's lyrical verse insincere and pretentious, Asrul Sani described the earlier group of writers as placid and dogmatic, inflexible in a new environment, while sitor Situmorang concluded that Pudjangga Baru was of limited relevance in the modern world. The critic H. B. Jassin commented succinctly that one sentence by Pramudya Ananta Tur encompassed all the experience of a novel by Takdir Alisjahbana. Sutan Sjahrir accused the litterateurs of the 'thirties of remaining preoccupied with "the bloodless, sugary, spiritless farce that they called their 'art." He added that "They cannot yet make a distinction between maudlin sentimentality and true, deep feeling." 59

Two factors combined to restrict Pudjangga Baru's ultimate impact: the nature of its audience, and the source from which the group drew most of their intellectual stimulation. As a "little magazine," it was by definition alienated from the general population. But Pudjangga Baru was also divorced from its society in a more significant way, for it attributed little importance to, and lacked a realistic appreciation of the people who would, after all, form the bulk of the population of the new Indonesia. Its writings even lacked the compensatory populist urges characteristic of the intellectuals of new states in the post-war era. Some commentators of the time, observing the great distance of the intelligentsia from the common man saw in it the loss of Oriental virtue and a callousing of the soul. But it was not so much that the intellectuals were hard as that they were uncomprehending. Western education, with all that such training involved, separated them from the culture which had hitherto served as a bond between the elite and the people. The Pudjangga Baru writers saw their society through the Dutch, relying on the Netherlands both for their general intellectual armory and for their knowledge of Indonesian culture. Hence they could be accused, in spite of their nationalist commitment, of having been "mentally colonized" by the Dutch. What happened to them was akin to what happened to the Indian intellectuals under the British, who "took partial possession of the Indian mind." To a large extent Indian intellectuals entered into a provincial relationship with England, depending "for their cultural sustenance on the intellectual output which emanates from metropolises located outside their country."60

59. Sjahrir, Out of Exile, p. 19. For some of the later criticisms, see H. B. Jassin, Kesusasteraan Modern dalam Kritiek dan Esei (Djakarta: Gunung Agung, 1954), I, Pp. 5152,57 .

60. Edward Shils, "The Intellectual Between Tradition and Modernity: The Indian Situation," Comparative Studies in Society and History (supplement I), 196I, Pp. II, 79. 
But seen in its historical context, Pudjangga Baru was a remarkable achievement. Indeed, the violence of the subsequent reaction against it indicates the degree to which the periodical dominated the intellectual world of its time. For Pudjangga Baru explored one possible type of intellectual development within the colonial situation, working to carve an Indonesian cultural identity using Dutch tools. If today this effort seems a curious product of tempo doeloe, it is largely because the particular outlook of Pudjangga Baru was bypassed by events. Had the radicalizing experience of Japanese occupation and revolution not occurred, Pudjangga Baru's approach might not appear so distant from the intellectual life of Indonesia in our day. As it was, the journal and the generation of writers associated with it accomplished much, not in terms of works which endured on their own strength but in terms of laying the foundation on which succeeding generations could build a national literature of aesthetic merit and social immediacy. 